Zeszyty Naukowe Szkoły Głównej Gospodarstwa Wiejskiego w Warszawie Problemy Rolnictwa Światowego tom 17 (XXXII), zeszyt 2, 2017: 267-286

DOI: $10.22630 /$ PRS.2017.17.2.45

Katarzyna Twarowska ${ }^{1}$

Uniwersytet Marii Curie-Skłodowskiej w Lublinie

\title{
Ocena pozycji walut kluczowych międzynarodowego systemu walutowego w latach 1990 - 2016 i perspektywy zmian
}

\section{Assessment of the Key Currencies in International Monetary System in 1990-2016 and the Perspective of Changes}

\begin{abstract}
Synopsis. Celem artykułu jest analiza i ocena pozycji walut kluczowych jako czynnika determinującego zmiany $\mathrm{w}$ funkcjonowaniu międzynarodowego systemu walutowego. Metodyka obejmuje badania teoretyczne (analityczne studia literatury naukowej i raportów badawczych) oraz badania empiryczne (analiza danych statystycznych BIS, IMF, SWIFT, EBC, UNCTAD). Przeprowadzona analiza pozwala na stwierdzenie, że główną walutą międzynarodową pozostaje dolar, a utworzenie obszaru wspólnej waluty w UE nie doprowadziło do oczekiwanych zmian pozycji głównych walut i uzyskania przez euro pozycji drugiej waluty globalnej, konkurującej skutecznie z dolarem w pełnieniu funkcji pieniądza światowego. Ponadto, rosnący od lat potencjał gospodarczy i handlowy Chin oraz transformacja układu sił gospodarczych nie znajduje odzwierciedlenia w zmianie pozycji walut krajów rozwijających się w pełnieniu funkcji pieniądza światowego. Prezentowane scenariusze transformacji MSW nie dają jednoznacznej odpowiedzi co do zmian znaczenia walut kluczowych, ale wprowadzenie jednej globalnej waluty wydaje się być zbyt trudne w obecnych warunkach.
\end{abstract}

Słowa kluczowe: waluta międzynarodowa, rezerwy walutowe, struktura walutowa, dolar, euro, scenariusze transformacji MSW

\begin{abstract}
The aim of the paper is to analyze and evaluate the position of the key currencies as a determinant of changes in the functioning of the international monetary system. Methodology includes theoretical studies (scientific literature and research reports) and empirical studies (statistical analysis of BIS, IMF, SWIFT, ECB, UNCTAD data). The analysis makes it possible to conclude that the dollar remains the main international currency, and the creation of a single currency area in the EU has not led to the expected changes in the main currencies positions as well as the euro has not reached the position of the second global currency competing effectively against the dollar as a global currency. Moreover, the growing economic and trade potential of China and the transformation of the global economic power are not reflected in the changes of developing countries' currencies positions in the functions of global money. The presented scenarios of the IMS transformation do not give a clear answer about the future of the key currencies, but the implementation of a single global currency seems too difficult in the current conditions.
\end{abstract}

Key words: international currency, foreign exchange reserves, currency composition, dollar, euro, scenarios of IMS transformation

\section{Wprowadzenie}

Pieniądz międzynarodowy jest jednym z najistotniejszych zagadnień współczesnych finansów międzynarodowych, ponieważ od tego, jak efektywnie pełni swoje funkcje zależy

${ }^{1}$ mgr, Katedra Gospodarki Światowej i Integracji Europejskiej UMCS, Plac Marii Curie-Skłodowskiej 5, 20-036 Lublin, e-mail: k.twarowska@umcs.pl 


\section{K. Twarowska}

sprawność międzynarodowego systemu walutowego. Od końca lat 90. problem lepszego dostosowania międzynarodowego systemu walutowego i finansowego do zmian strukturalnych $\mathrm{w}$ gospodarce światowej znalazł się w centrum dyskusji środowisk akademickich i biznesowych. Poświęcono temu zagadnieniu wiele ekspertyz i prac naukowych. W literaturze wymienia się wiele wad funkcjonującego systemu walutowego, między innymi: destabilizujące skutki gwałtownych ruchów kapitału, niedostosowania kursów walutowych oraz nadmierną rolę Systemu Rezerwy Federalnej jako pożyczkodawcy zabezpieczającego międzynarodową płynność finansową.

Powyższe uwarunkowania są istotną przesłanką do przeprowadzenia badań, których celem jest analiza i ocena pozycji walut kluczowych jako czynnika determinującego zmiany w funkcjonowaniu międzynarodowego systemu walutowego. Autorka podejmuje ponadto próbę weryfikacji hipotezy, że wspótczesny międzynarodowy system walutowy oparty na walutach kluczowych nie odzwierciedla istniejqcego ukladu sit gospodarczych i rozważa różne scenariusze zmiany zasad funkcjonowania międzynarodowego porządku walutowego oraz ich skutki, a także problemy prowadzące do narastania globalnych nierównowag.

Autorka jest świadoma złożoności problemu oraz tego, że zagadnienia związane z pieniądzem międzynarodowym mogą być rozpatrywane również na gruncie nauk politycznych i społecznych, jednak ze względu zarówno na same zainteresowania autorki, jak i ograniczenia formalne niniejsza analiza skupia się na problemach ekonomicznych.

\section{Przegląd literatury}

Cechą wspólną definicji pieniądza międzynarodowego jest stwierdzenie, że pieniądz zyskuje status waluty międzynarodowej, jeżeli jest wykorzystywany poza granicami kraju emitującego daną walutę, jako środek płatniczy, jednostka rozliczeniowa i środek przechowywania wartości - tezauryzacji (Chinn i Frankel, 2005). Waluty międzynarodowe, które umacniają swoją pozycję $\mathrm{w}$ sferze prywatnej $\mathrm{i}$ oficjalnej, stają się wówczas kluczowymi walutami międzynarodowego systemu walutowego (Mucha-Leszko i Kąkol, 2013). Szczegółowe funkcje waluty międzynarodowej zostały zaprezentowane w tabeli 1 .

Tabela 1. Funkcje pieniądza międzynarodowego

Table 1. Functions of an international currency

\begin{tabular}{l|ll}
\hline \multicolumn{1}{c|}{ Funkcje pieniądza } & \multicolumn{1}{|c}{ Sektor prywatny } & \multicolumn{1}{c}{ Sektor publiczny } \\
\hline Środek tezauryzacji & $\begin{array}{l}\text { waluta inwestycyjna } \\
\text { waluta transakcji w handlu } \\
\text { międzynarodowym i w wymianie walut }\end{array}$ & $\begin{array}{l}\text { waluta rezerwowa } \\
\text { Środek płatniczy }\end{array}$ \\
Jednostka rozliczeniowa & waluta fakturowania i notowania cen & $\begin{array}{l}\text { waluta odniesienia dla kursów } \\
\text { walutowych }\end{array}$ \\
\hline
\end{tabular}

Źródło: (Kenen, 1983, s. 16) 
Literatura światowa i polska wskazuje na liczne czynniki determinujące proces umiędzynarodowienia waluty. ${ }^{2}$ M. Chinn i J.A. Frankel (2007) wyodrębniają cztery główne grupy czynników wpływających na uzyskanie przez walutę pozycji pieniądza międzynarodowego:

- $\quad$ udział kraju w światowej produkcji i handlu oraz inne wskaźniki określające udział w gospodarce światowej,

- rynek finansowy kraju emitenta - otwarty, płynny i dobrze rozwinięty,

- zaufanie do waluty i przewidywalność jej wartości,

- efekty zewnętrzne sieci (network externalities), polegające na tym, że wykorzystanie waluty $\mathrm{w}$ transakcjach międzynarodowych wywołuje efekt wzmacniający, który zwiększa prawdopodobieństwo dalszego jej stosowania.

Z kolei G.G. Galati i P. Wooldridge (2006) wskazują na czynniki warunkujące wykorzystywanie pieniądza $\mathrm{w}$ funkcji waluty rezerwowej, która $\mathrm{z}$ jednej strony jest pochodną pełnienia przez walutę pozostałych funkcji pieniądza międzynarodowego, a z drugiej strony staje się przesłanką do wyboru danej waluty zarówno w funkcjach sfery oficjalnej (waluta zaczepu i interwencji na rynku walutowym) oraz prywatnej (np. rozliczania handlu międzynarodowego). Wymienione czynniki to po pierwsze, wielkość gospodarki emitenta waluty i jej pozycja w gospodarce światowej (udział w handlu). Również B. Eichengreen (1998) i J.A. Frankel (2000) w swoich analizach dowodzą, że im silniejsza pozycja kraju w gospodarce światowej, tym większe prawdopodobieństwo, że inne kraje będą stosowały daną walutę jako walutę zaczepienia oraz $w$ funkcjach związanych z handlem międzynarodowym. Obliczyli, że wzrost udziału o jeden punkt procentowy kraju, którego waluta pełni funkcje pieniądza światowego, w produkcie globalnym (obliczonym wg PPP) powoduje zwiększenie udziału tej waluty w rezerwach banków centralnych o 1,33 pkt procentowych (za: Mucha-Leszko, 2007, s. 280). B. Eichengreen w 1997 roku zweryfikował obliczenia oceniając wzrost udziału waluty w globalnych rezerwach na 0,9 pkt procentowego. Zauważyć jednak należy, że zależność między udziałem gospodarki emitenta $w$ światowej produkcji i handlu nie jest proporcjonalna do udziału waluty $\mathrm{w}$ światowych rezerwach walutowych, ponieważ występuje efekt opóźnienia, czego przykładem było utrzymywanie się pozycji funta szterlinga długo po utraceniu przez Wielką Brytanię dominacji w gospodarce światowej (początek XX wieku) czy status dolara jako głównej waluty światowej po upadku systemu walutowego z Bretton Woods i ewolucji porządku Pax Americana w kierunku układu policentrycznego z trzema dominującymi ośrodkami. Ponadto, tradycja rozliczania handlu pewnymi surowcami, np. ropą naftową sprawia, że w tym obszarze dominuje dolar amerykański (Eichengreen, 2005).

Drugim czynnikiem jest stabilność makroekonomiczna. P. Hartmann i O. Issing (2002) dowodzą, jak ważna jest stabilność cen na rynku wewnętrznym z punktu widzenia uzyskania i utrzymania przez walutę statusu rezerwowej. M. Devereux i S. Shi (2005, za: Galati i Wooldridge, 2006) w teoretycznych rozważaniach udowadniaja, że w ekstremalnych przypadkach pieniądz może stracić pozycję waluty rezerwowej w następstwie dużego wzrostu inflacji w gospodarce emitenta. Zatem, stabilność makroekonomiczna wynikająca z polityki gospodarczej oraz warunków instytucjonalnoprawnych państwa emitującego walutę warunkuje zaufanie do tej waluty.

${ }^{2}$ Przegląd badan teoretycznych oraz empirycznych dotyczących czynników determinujących pozycję walut międzynarodowych przedstawiono m.in. w: (Chinn i Frankel, 2007). 
Trzecim czynnikiem jest rozwój rynku finansowego. B. Eichengreen (1998) podkreśla, że im większy i bardziej płynny jest rynek finansowy kraju emitującego walutę, tym większe prawdopodobieństwo, że inne kraje wybiorą daną walutę do dokonywania interwencji walutowych. Ponadto, istotna jest efektywność, bezpieczeństwo i konkurencyjność rynku finansowego oraz niezależność banku centralnego.

Czwartym czynnikiem są efekty zewnętrzne sieci (network externalities). Wynikają one $\mathrm{z}$ tego, że im częściej waluta stosowana jest jako środek wymiany, to koszty transakcyjne związane $\mathrm{z}$ jej zastosowaniem są niższe, a płynność wyższa, zatem waluta staje się bardziej atrakcyjna. Efekt ten może być porównywany do korzyści skali (Cooper, 2000). Efekty zewnętrzne sieci prowadzą do centralizacji międzynarodowego systemu walutowego, ponieważ przynoszą korzyści zaledwie kilku bądź tylko jednej walucie (Gaspar, 2004). Efekt ten może być jednak ograniczany przez potrzebę dywersyfikacji zmniejszającej ryzyko. Jak zauważa B.J. Cohen (2000), istotną cechą czynników determinujących pozycję walut kluczowych jest tendencja do powolnych zmian $\mathrm{i}$ ich długotrwały charakter, określając to zjawisko inercją.

Również w polskiej literaturze można znaleźć ważny wkład do dyskusji na temat czynników wpływających na umiędzynarodowienie waluty. L. Oręziak (2001) podkreśla, że podstawowe znaczenie dla pełnienia przez walutę funkcji pieniądza międzynarodowego ma zaufanie uczestników rynków finansowych do danej waluty oraz do państwa emitenta. Z kolei B. Mucha-Leszko (2007) zauważa, że o atrakcyjności waluty decydują również czynniki krótkookresowe, czyli stopy procentowe i kursy walutowe. Ponadto, internacjonalizacja walut była przedmiotem badań między innymi I. Pszczółki (2011) oraz J. Bilskiego (2015).

Podsumowując, można stwierdzić, że wykorzystywanie waluty międzynarodowej w sektorze prywatnym i publicznym jest ściśle ze sobą powiązane, jednak trudno jest jednoznacznie określić, w jaki sposób funkcje te wzajemnie na siebie wpływają. E.M. Truman (2004) twierdzi, że status waluty międzynarodowej jest głównie pochodną wykorzystania jej przez sektor prywatny. Jednak, jak wskazują badania, w ostatnich latach coraz większe znaczenia dla wyboru waluty przez sektor prywatny zyskują decyzje rządów i władz monetarnych dotyczące m.in. akumulacji rezerw walutowych. Analiza BIS (2005) obejmująca lata 2002-2004 wskazuje, że rynek walutowy był bardzo wrażliwy na sygnały o dywersyfikacji rezerw walutowych i odchodzenia od dolara.

\section{Dane i metody}

Celem analizy empirycznej jest ocena pozycji walut kluczowych w pełnieniu funkcji pieniądza międzynarodowego, wskazanie czynników determinujących znaczenie poszczególnych walut oraz zaprezentowanie perspektyw zmian.

Opracowanie zawiera analizę danych źródłowych, na podstawie której sformułowane zostały wnioski oceniające pozycję walut kluczowych. Badania obejmują lata 1990-2016. Zaprezentowane zostały również prognozy dotyczące zmian MSW.

Ocena pozycji walut $\mathrm{w}$ głównych funkcjach pieniądza międzynarodowego została przeprowadzona $\mathrm{w}$ oparciu o dane statystyczne pochodzace $\mathrm{z}$ baz danych oraz raportów Międzynarodowego Funduszu Walutowego (IMF), Banku Rozrachunków Międzynarodowych, UNCTAD, Europejskiego Banku Centralnego, systemu SWIFT 
(Society for Worldwide Interbank Financial Telecommunication). Podstawą do formułowania wniosków były również badania przeprowadzone przez innych autorów.

\section{Wyniki badań: charakterystyka głównych ośrodków gospodarki światowej}

Współczesna gospodarka światowa charakteryzuje się dominacją kilku ośrodków. Pod względem udziału w światowym PKB (wg PPP) największym krajem na świecie do 2013 roku były Stany Zjednoczone, ale od 2014 roku utraciły tę pozycję na rzecz Chin. Należy również podkreślić wysoki udział krajów Unii Europejskiej zarówno w światowym PKB, światowym eksporcie i imporcie, a także w światowych przepływach kapitału. Charakterystykę głównych centrów gospodarki światowej uzupełniają dane o kondycji finansów publicznych (tab. 2), gdyż zbyt wysoki dług publiczny i deficyt może negatywnie wpływać na zaufanie do waluty danego kraju. Najwyższe zadłużenie publiczne w 2015 roku miała Japonia (248\% PKB) i Stany Zjednoczone (102\% PKB), jednak w przypadku USA fakt ten nie powodował odwrócenia się podmiotów zagranicznych od dolara.

Tabela 2. Charakterystyka głównych ośrodków gospodarki światowej w latach 1990 i 2015

Table 2. Characteristics of the main centers of the world economy in 1990 and 2015

\begin{tabular}{|c|c|c|c|c|c|c|c|c|c|c|}
\hline \multirow{2}{*}{ Wskaźniki } & \multicolumn{2}{|c|}{ UE } & \multicolumn{2}{|c|}{ Strefa euro } & \multicolumn{2}{|c|}{ USA } & \multicolumn{2}{|c|}{ Japonia } & \multicolumn{2}{|c|}{ Chiny } \\
\hline & 1990 & 2015 & 1999 & 2015 & 1990 & 2015 & 1990 & 2015 & 1990 & 2015 \\
\hline $\begin{array}{l}\text { Udział w światowym PKB (wg } \\
\text { PPP, w \%) }\end{array}$ & 27,6 & 16,9 & bd. & bd. & 22,1 & 15,8 & 8,7 & 4,2 & 4,1 & 17,3 \\
\hline $\begin{array}{l}\text { Udział w światowym eksporcie } \\
\text { towarów (w \%) }\end{array}$ & 44,7 & 32,5 & 35,4 & 25,0 & 11,3 & 9,1 & 8,2 & 3,8 & 1,8 & 13,7 \\
\hline $\begin{array}{l}\text { Udział w światowym imporcie } \\
\text { towarów }(\mathrm{w} \%)\end{array}$ & 45,0 & 31,4 & 35,1 & 25,0 & 14,3 & 13,9 & 6,5 & 3,9 & 1,5 & 10,1 \\
\hline $\begin{array}{l}\text { Udział w światowych zasobach } \\
\text { ZIB (kraj odpływu, w \%) }\end{array}$ & 43,3 & 37,3 & 30,5 & 28,6 & 32,5 & 23,9 & 8,9 & 4,9 & 0,2 & 4,0 \\
\hline $\begin{array}{l}\text { Udział w światowych zasobach } \\
\text { ZIB (kraj lokaty, w \%) }\end{array}$ & 40,2 & 31,1 & 29,8 & 21,5 & 24,6 & 22,4 & 0,4 & 0,7 & 0,9 & 4,9 \\
\hline Dług publiczny $(\% \mathrm{PKB})$ & $61,4^{1}$ & 86,8 & 70,6 & 92,5 & $53,0^{2}$ & 105,2 & 67,0 & 248,0 & $21,4^{3}$ & 42,9 \\
\hline Saldo budżetu państwa (\% PKB) & $-4,6^{4}$ & $-2,3$ & $-1,5$ & $-2,1$ & $-0,6^{2}$ & $-3,5$ & 1,7 & $-5,2$ & $-0,7$ & $-2,7$ \\
\hline Inflacja (w \%) & 27,5 & 0,0 & 1,2 & 0,0 & 5,4 & 0,1 & 3,1 & 0,8 & 3,1 & 1,4 \\
\hline $\begin{array}{l}\text { Saldo rachunku obrotów bieżących } \\
(\% \text { PKB) }\end{array}$ & $-0,6$ & 2,1 & $-1,9$ & 3,2 & $-1,3$ & $-2,6$ & 1,4 & 3,3 & $3,8^{5}$ & 3,0 \\
\hline $\begin{array}{l}\text { LIBOR 6-miesięczny ( } 3 \text { - } \\
\text { miesięczny UE i strefa euro) w \% }\end{array}$ & bd. & bd. & 3,0 & 0,0 & 8,3 & 0,5 & 7,8 & 0,1 & bd. & bd. \\
\hline
\end{tabular}

Źródło: opracowanie własne na podstawie: (IMF, 2017; UNCTAD, 2017).

Ponadto, do czynników, które w krótkim okresie mogą oddziaływać na atrakcyjność waluty jest poziom inflacji oraz rynkowa stopa procentowa. Na początku lat 90 . wysoka stopa procentowa w Japonii i w USA przyciągała inwestycje, głównie o charakterze spekulacyjnym. W 2015 roku stopy procentowe w analizowanych krajach były na niskim 
i zbliżonym poziomie, nie występował również problem rosnących cen, a wręcz przeciwnie, pojawiało się zagrożenie deflacją.

\section{Wyniki badań: ocena pozycji walut kluczowych w sferze prywatnej}

Oceniając pozycję walut kluczowych w sferze prywatnej wyróżnić można kilka obszarów analizy:

- wykorzystanie walut do fakturowania handlu oraz płatności związanych $\mathrm{z}$ wymianą międzynarodową (ocena pozycji walut $\mathrm{W}$ funkcji jednostki rozliczeniowej - waluta fakturowania; środka płatniczego - płatności związane z wymianą handlową),

- pozycję walut $\mathrm{w}$ transakcjach na międzynarodowym rynku finansowym (ocena pozycji walut w funkcji środka tezauryzacji - waluta inwestycyjna; środka płatniczego - wymiana walut na rynku walutowym).

Wybór waluty fakturowania eksportu jest jedną z kluczowych decyzji podmiotów gospodarczych sprzedających swoje towary i usługi na rynkach zagranicznych, ponieważ wiąże się z dwojakiego rodzaju ryzykiem: kursowym oraz popytowym (Białowąs, 2016). Wybór własnej waluty eliminuje ryzyko kursowe, ale aprecjacja waluty może skutkować spadkiem popytu na eksportowane towary. Z kolei wybór waluty importera wiąże się z powstaniem ryzyka zmiany kursu walutowego, co może niekorzystnie wpływać na rachunek ekonomiczny eksportera.

Tabela 3. Wykorzystanie euro i dolara w fakturowaniu eksportu i importu wybranych krajów w latach 1999-2010 (w \%)

Table 3. Use of the euro and the US dollar for invoicing in exports and imports of different countries in 1999-2010 (in \%)

\begin{tabular}{|c|c|c|c|c|c|c|c|c|c|}
\hline \multirow{2}{*}{ Kraje } & \multicolumn{2}{|c|}{ Eksport } & \multicolumn{2}{|c|}{ Import } & \multirow{2}{*}{ Kraje } & \multicolumn{2}{|c|}{ Eksport } & \multicolumn{2}{|c|}{ Import } \\
\hline & EUR & USD & EUR & USD & & EUR & USD & EUR & USD \\
\hline \multicolumn{5}{|c|}{ Wybrane kraje ze strefy euro } & \multicolumn{5}{|c|}{ Kraje UE spoza strefy euro } \\
\hline Słowenia & 83,23 & 9,58 & 74,87 & 14,86 & Węgry & 78,64 & 16,40 & 69,86 & 21,34 \\
\hline Słowacja & 74,66 & 25,40 & 78,80 & bd. & Czechy & 71,64 & 13,63 & 68,21 & 19,22 \\
\hline Niemcy & 61,72 & 26,60 & 54,83 & 34,77 & Chorwacja & 69,19 & 31,06 & 73,92 & 22,21 \\
\hline Włochy & 61,61 & 24,80 & 45,66 & 34,30 & Rumunia & 63,43 & 36,36 & 67,17 & 30,91 \\
\hline Estonia & 60,93 & 9,20 & 58,39 & 21,95 & Polska & 62,94 & 31,83 & 58,25 & 30,57 \\
\hline Hiszpani & 57,87 & 35,61 & 54,22 & 41,71 & Portugalia & 54,12 & 31,73 & 53,61 & 34,73 \\
\hline Belgia & 53,63 & 30,97 & 53,73 & 34,20 & Bułgaria & 53,20 & 50 , & 58,37 & 42,89 \\
\hline Luksemburg & 52,69 & 29,00 & 43,66 & 40,23 & Dania & 32,88 & 21,95 & 33,90 & 20,45 \\
\hline Łotwa & 50,71 & 39,60 & 56,54 & 35,66 & Wielka Brytania & 21,00 & 27,75 & 22,00 & 34,75 \\
\hline Francja & 50,33 & 37,94 & 43,14 & 48,68 & \multicolumn{5}{|c|}{ Wybrane kraje spoza Europy } \\
\hline Holandia & 49,56 & 35,94 & 41,90 & 47,00 & $\overline{A l g}$ & 0,53 & 99,00 & 49,40 & bd. \\
\hline Litwa & 46,34 & 50,03 & 49,09 & 47,70 & Indonezja & 1,67 & 92,59 & 4,86 & 80,43 \\
\hline Grecja & 37,93 & 54,35 & 35,96 & 57,15 & Pakistan & 4,00 & 91,43 & 6,50 & 83,87 \\
\hline Cypr & 18,55 & bd. & 9,95 & bd. & Tajlandia & 2,24 & 86,67 & 3,93 & 78,33 \\
\hline \multicolumn{5}{|c|}{ Wybrane kraje europejskie spoza UE } & Korea Płd. & 4,93 & 85,90 & 4,35 & 80,38 \\
\hline Macedonia & 68,17 & 35,80 & 67,24 & 33,71 & Australia & 0,94 & 71,17 & 8,47 & 51,12 \\
\hline Turcja & 47,77 & 43,47 & 36,52 & 55,60 & RPA & 17,00 & 52,00 & bd. & bd. \\
\hline Ukraina & 6,09 & 76,28 & 16,42 & 74,77 & Indie & 7,10 & bd. & 8,10 & bd. \\
\hline
\end{tabular}

Źródło: (Lai i Yu, 2014, s. 29).

Do czynników determinujących wybór waluty fakturowania oraz płatności związanych z wymianą handlową należą zarówno czynniki o charakterze ogólnym, 
wymienione we wcześniejszych punktach niniejszego opracowania, jak również czynniki specyficzne, takie jak siła przetargowa producentów i konkurencja między firmami, stopień organizacji rynku, stopień zróżnicowania dóbr, waluta zakupu dóbr pośrednich, podzespołów i surowców oraz wielkość jednorazowej dostawy (Bacchetta i van Wincoop, 2002; Goldberg i Tille, 2009).

Stosując jako kryterium oceny udział walut $\mathrm{w}$ fakturowaniu eksportu i importu, poza Europa zdecydowaną przewage posiada dolar amerykański (tab. 3). Jedynie w przypadku krajów europejskich pierwszą walutą jest euro, przy czym występuje duże zróżnicowanie $\mathrm{w}$ wykorzystaniu waluty euro pomiędzy tymi krajami. Spośród zaprezentowanych w tabeli 3 krajów należących do strefy euro, najwyższy odsetek eksportu fakturowanego w walucie euro w latach 1999-2010 miały Słowenia $(83,23 \%)$ i Słowacja $(74,66 \%)$, natomiast najniższy Cypr $(18,55 \%)$ i Grecja $(37,93)$, co wynika z ich powiązań handlowych z krajami spoza Unii Europejskiej.

Na rysunku 1 zaprezentowano udziały walut w płatnościach związanych $\mathrm{z}$ handlem międzynarodowym. Pierwsze miejsce zajmuje dolar, którego udział wzrósł z 47,6\% w 2012 roku do 51,9\% w 2014. Drugą walutą jest euro, jednak w tym przypadku nastąił spadek udziału z 33\% w 2012 roku do 30,5\% w 2014. Udział kolejnej waluty - funta szterlinga, jest istotnie mniejszy i wynosił w 2014 roku 5,4\%. Dalej w rankingu znalazł się jen (5 miejsce $\mathrm{z}$ udziałem $1,8 \%$ ) i chiński renminbi (miejsce $11 \mathrm{z}$ udziałem $0,5 \%$ ). Zauważalny jest tutaj pewien dysparytet pomiędzy znaczeniem chińskiej waluty $\mathrm{w}$ rozliczeniach związanych $\mathrm{z}$ handlem międzynarodowym a udziałem Chin w światowym eksporcie i imporcie. Silna pozycja Chin jako światowego eksportera stwarza potencjalne możliwości zwiększenia roli chińskiej waluty. Ponadto, rząd Chin również podejmuje działania, między innymi o charakterze infrastrukturalnym, w celu umocnienia pozycji renminbi jako waluty międzynarodowej.

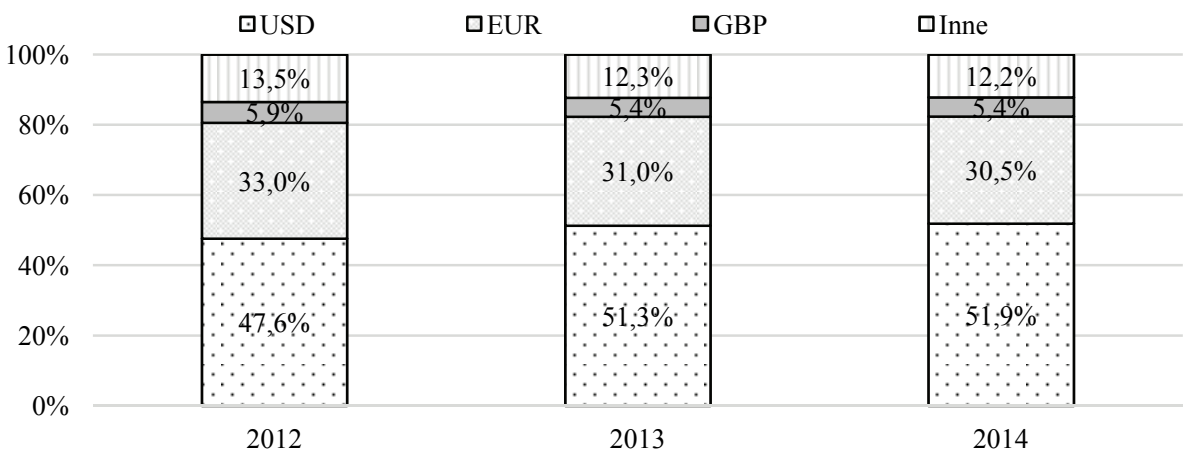

Rys. 1. Udział walut w płatnościach związanych $\mathrm{z}$ handlem międzynarodowym (w \%)

Fig. 1. Shares of main currencies used in international trade (in \%)

Źródło: (SWIFT, 2015, s. 7).

Analiza transakcji międzykontynentalnych (inter-regional): pomiędzy Ameryka, Europą i Azją pozwala na jeszcze lepszą ocenę umiędzynarodowienia walut. Dane zaprezentowane na rysunku 2 wskazują na dużą przewagę dolara, którego udział w IV kwartale 2014 roku wynosił 79,5\% i przewyższał ponad 13-krotnie udział kolejnej waluty - 
euro $(5,9 \%)$. Kolejne waluty to jen japoński (3,3\%), funt brytyjski $(3,2 \%)$ i dolar kanadyjski $(2,3 \%)$.

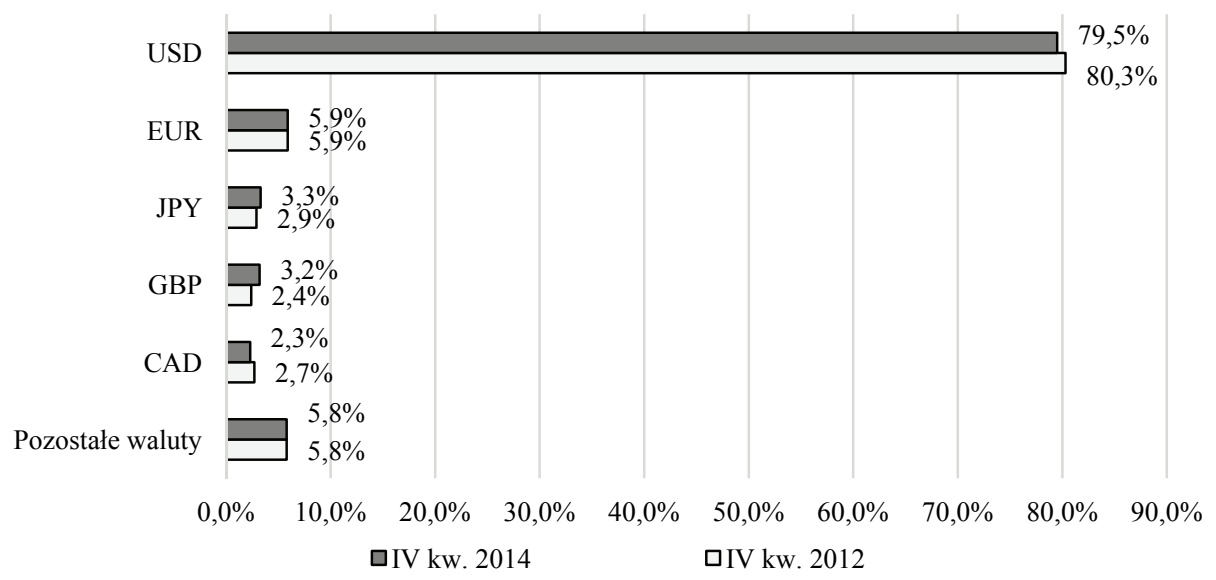

Rys. 2. Udział głównych walut w handlu międzykontynentalnym w IV kw. 2012 i 2014 roku (w \%)

Fig. 2. Shares of main currencies used in inter-regional trade in Q4 2012 and Q4 2014 (in \%)

Źródło: (SWIFT, 2015, s. 8).

Warto podkreślić, że w analizowanym okresie (IV kw. 2012 - IV kw. 2014) obroty w handlu międzykontynentalnym zwiększyły się o $21 \%$, a największy przyrost wystąpił w eksporcie z Europy do obu Ameryk (o $32 \%$ ), z kolei przepływy w odwrotnym kierunku wzrosły jedynie o 4\% (SWIFT, 2015, s. 8). Wysoką dynamikę miały również przepływy z Ameryk do Azji (wzrost o 28\%). Dane za kolejne lata oraz prognozy wskazuja jednak na spadek dynamiki w handlu światowym. Według UNCTAD w 2015 roku globalny eksport towarów przemysłowych zmniejszył się o $12,87 \%$. Z kolei IMF (2017) przewiduje, że średnia dynamika wzrostu światowego eksportu towarów w latach 2017-2021 wyniesie $3,9 \%$, w strefie euro $3,91 \%$, w USA $5,74 \%$, a w Chinach zaledwie $2,72 \%$. Spadek dynamiki prognozowany jest w krajach rozwijających się, które w rozliczeniach handlu stosują głównie dolary amerykańskie, co w kolejnych latach może wpłynąć na spadek udziału dolara $\mathrm{w}$ funkcjach waluty międzynarodowej związanych $\mathrm{z}$ wymianą międzynarodową.

Podsumowując, utrzymująca się przez dziesięciolecia silna pozycja dolara jako waluty fakturowania i płatności związanych $\mathrm{z}$ handlem międzynarodowym wynika nie tylko $\mathrm{z}$ dużego udziału USA $\mathrm{w}$ gospodarce światowej (światowej produkcji, eksporcie $\mathrm{i}$ imporcie), ale przede wszystkim z zaufania do waluty i historycznych przyzwyczajeń. W przypadku dolara można stwierdzić, że jest to waluta w pełni globalna, ponieważ wykorzystywana jest $\mathrm{w}$ transakcjach na całym świecie.

Zastosowanie euro jako waluty fakturowania oraz rozliczeń $w$ transakcjach handlowych pozostaje $\mathrm{w}$ ścisłym związku z dużym udziałem UE w handlu światowym (Mucha-Leszko, 2013), jednak euro pozostaje walutą regionalną, gdyż jest stosowane głównie przez kraje europejskie, natomiast w krajach spoza Europy znaczenie euro jest marginalne.

$\mathrm{Z}$ kolei wysoki udział Chin $\mathrm{w}$ handlu światowym nie znajduje jeszcze proporcjonalnego odzwierciedlenia $\mathrm{w}$ roli renminbi jako waluty rozliczania i fakturowania 
handlu. Wskazuje to jednak na duży potencjał chińskiej waluty do uzyskania statusu waluty kluczowej, jednak pod warunkiem, że wzrośnie zaufanie uczestników rynku do tej waluty.

O umiędzynarodowieniu waluty świadczy również jej wykorzystanie na międzynarodowym rynku finansowym. Biorąc jako kryterium rodzaj stosowanych instrumentów wyróżnić można trzy podstawowe segmenty międzynarodowego rynku finansowego: rynek walutowy, pieniężny i kapitałowy. Rynek walutowy rozwinął się po upadku systemu walutowego z Bretton Woods (Mucha-Leszko, 2005, s. 55) i upłynnieniu przez większość krajów kursów walutowych. Jest to rynek duży ${ }^{3}$ i dynamicznie rozwijający się. Średnie dzienne obroty na rynku walutowym wzrosły z 640 mld USD w 1989 roku do 5355 mld USD w 2013 roku, a następnie obroty spadty do 5088 mld USD w 2016 roku (rys. 3 i tab. 4). Spadek dotyczył transakcji natychmiastowych, a w przypadku transakcji terminowych utrzymuje się trend wzrostowy.

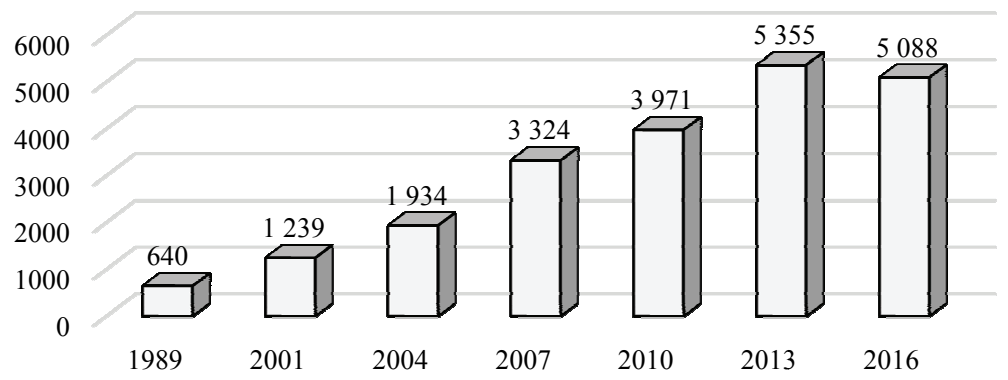

Rys. 3. Średnie dzienne obroty na rynku walutowym (w kwietniu, w mld USD)

Fig. 3. The average daily OTC foreign exchange turnover (in April, billion USD)

Źródło: opracowanie własne na podstawie: (BIS, 2016).

Tabela 4. Struktura obrotów na międzynarodowym rynku walutowym według udziału poszczególnych rodzajów instrumentów w latach $2001-2016$

Table 4. The structure of OTC foreign exchange turnover by type of instruments in 2001-2016

\begin{tabular}{r|rrrrrr}
\hline Instrument & 2001 & 2004 & 2007 & 2010 & 2013 & 2016 \\
\hline Foreign exchange instruments & 1239 & 1934 & 3324 & 3971 & 5355 & 5088 \\
Transakcje natychmiastowe (spot transactions) & 386 & 631 & 1005 & 1488 & 2046 & 1654 \\
Kontrakty forward (outright forwards) & 130 & 209 & 362 & 475 & 679 & 700 \\
FX swap (foreign exchange swaps) & 656 & 954 & 1714 & 1759 & 2239 & 2383 \\
Swapy walutowe (currency swaps) & 7 & 21 & 31 & 43 & 54 & 96 \\
Opcje i inne instrumenty pochodne (options and other products) & 60 & 119 & 212 & 207 & 337 & 254 \\
\hline
\end{tabular}

Źródło: opracowanie własne na podstawie: (BIS, 2016).

Struktura obrotów na międzynarodowym rynku walutowym według instrumentów i rodzaju operacji w kwietniu 2016 roku została zaprezentowana na rysunku 4.

${ }^{3}$ Dzienne obroty na rynku walutowym w kwietniu 2016 roku stanowiły $6,8 \%$ światowego PKB, 24,3\% światowego eksportu towarów i usług (IMF, 2017). 


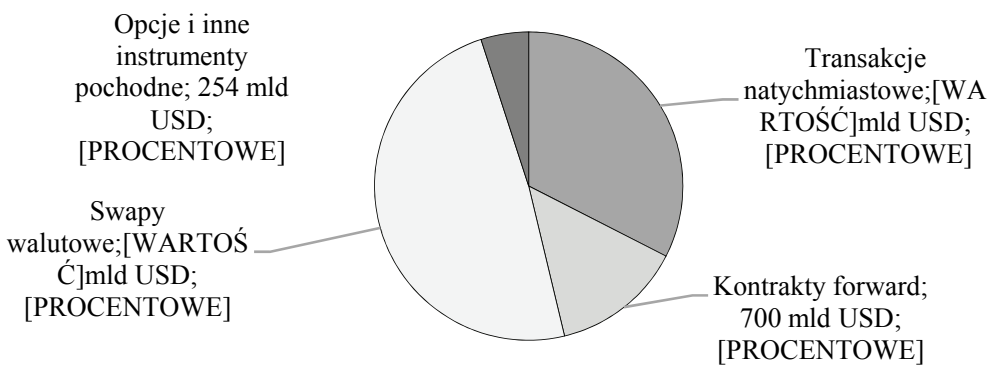

Rys. 4. Struktura obrotów na międzynarodowym rynku walutowym według udziału poszczególnych rodzajów instrumentów w kwietniu $2016 \mathrm{r}$

Fig. 4. The structure of OTC foreign exchange turnover by type of instruments in April 2016

Źródło: opracowanie własne na podstawie: (BIS, 2016).

W obrotach na rynku walutowym dolar również posiada istotną przewagę nad kolejnymi walutami (rys. 5 i tab. 5).

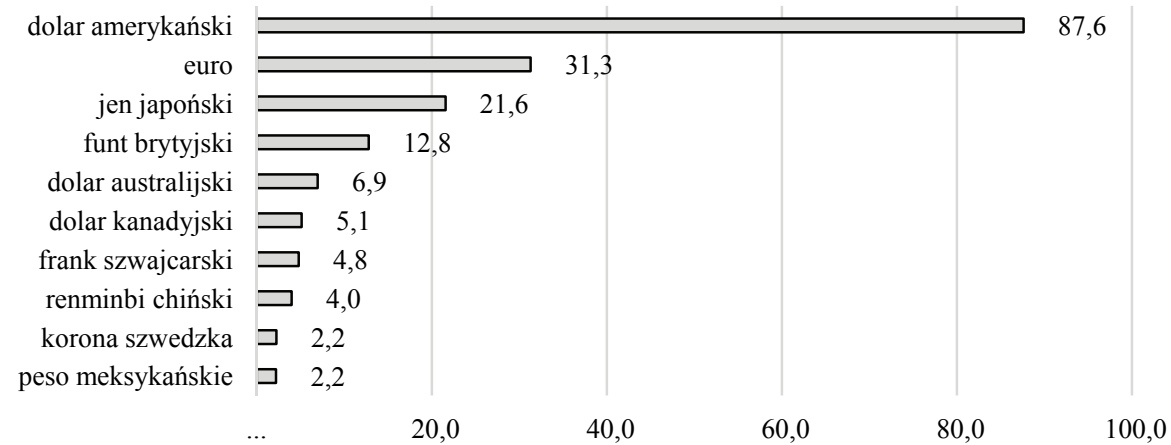

Uwaga: udział został obliczony na podstawie średnich dziennych obrotów w kwietniu. Ponieważ w każdej transakcji występują co najmniej dwie waluty, suma udziałów wynosi $200 \%$.

Rys. 5. Udział walut w globalnych obrotach na rynku FOREX w kwietniu 2016 r. (w \%)

Fig. 5. Currency distribution of OTC foreign exchange turnover in April 2016 (in \%)

Źródło: opracowanie własne na podstawie: (BIS, 2016).

W okresie od 2001 roku pierwsza czwórka walut pod względem obrotów na rynku walutowym pozostawała ta sama, przy czym udział dolara amerykańskiego do 2010 roku spadał. Tendencja zmieniła się i w 2013 oraz 2016 roku odnotowano wzrost udziału tej waluty, co mogło być związane ze wzrostem ryzyka na rynku walutowym i kryzysem finansowo-gospodarczym. W początkowej fazie kryzysu rosła niechęć uczestników rynku do dolara amerykańskiego, którego wartość spadała. Jednak w kolejnych latach kapitał ponownie zaczął płynąc do USA, a dolar był postrzegany jako waluta relatywnie bezpieczna. 
Tabela 5. Udział walut w globalnych obrotach na rynku FOREX (w \%)

Table 5. Currency distribution of OTC foreign exchange turnover (in \%)

\begin{tabular}{|c|c|c|c|c|c|c|c|c|c|c|c|c|}
\hline \multirow[b]{2}{*}{ Waluta } & \multicolumn{2}{|c|}{2001} & \multicolumn{2}{|c|}{2004} & \multicolumn{2}{|c|}{2007} & \multicolumn{2}{|c|}{2010} & \multicolumn{2}{|c|}{2013} & \multicolumn{2}{|c|}{2016} \\
\hline & 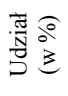 & $\begin{array}{l}\text { 苋 } \\
\text { స్. } \\
0\end{array}$ & 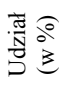 & $\begin{array}{l}\frac{\pi}{0} \\
\text { 岕 } \\
0 \\
2\end{array}$ & 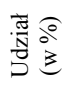 & $\begin{array}{l}\stackrel{0}{0} \\
\stackrel{0}{0} \\
\stackrel{0}{0}\end{array}$ & 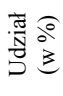 & $\begin{array}{l}\frac{\pi}{0} \\
\text { రু } \\
0 \\
0\end{array}$ & $\begin{array}{l}\text { 恶 } \mathrm{o} \\
\text { D } 3\end{array}$ & $\begin{array}{l}\frac{\pi}{2} \\
\text { 崩 } \\
0 \\
2\end{array}$ & 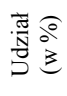 & 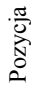 \\
\hline dolar amerykański (USD) & 89,9 & 1 & 88,0 & 1 & 85,6 & 1 & 84,9 & 1 & 87,0 & 1 & 87,6 & 1 \\
\hline euro (EUR) & 37,9 & 2 & 37,4 & 2 & 37,0 & 2 & 39,1 & 2 & 33,4 & 2 & 31,3 & 2 \\
\hline jen japoński (JPY) & 23,5 & 3 & 20,8 & 3 & 17,2 & 3 & 19,0 & 3 & 23,1 & 3 & 21,6 & 3 \\
\hline funt brytyjski (GBP) & 13,0 & 4 & 16,5 & 4 & 14,9 & 4 & 12,9 & 4 & 11,8 & 4 & 12,8 & 4 \\
\hline dolar australijski (AUD) & 4,3 & 7 & 6,0 & 6 & 6,6 & 6 & 7,6 & 5 & 8,6 & 5 & 6,9 & 5 \\
\hline dolar kanadyjski (CAD) & 4,5 & 6 & 4,2 & 7 & 4,3 & 7 & 5,3 & 7 & 4,6 & 7 & 5,1 & 6 \\
\hline frank szwajcarski (CHF) & 6,0 & 5 & 6,0 & 5 & 6,8 & 5 & 6,3 & 6 & 5,2 & 6 & 4,8 & 7 \\
\hline renminbi chiński (CNY) & 0,0 & 35 & 0,1 & 29 & 0,5 & 20 & 0,9 & 17 & 2,2 & 9 & 4,0 & 8 \\
\hline korona szwedzka (SEK) & 2,5 & 8 & 2,2 & 8 & 2,7 & 9 & 2,2 & 9 & 1,8 & 11 & 2,2 & 9 \\
\hline peso meksykańskie (MXN) & 0,8 & 14 & 1,1 & 12 & 1,3 & 12 & 1,3 & 14 & 2,5 & 8 & 2,2 & 10 \\
\hline
\end{tabular}

Źródło: opracowanie własne na podstawie: (BIS, 2016).

W transakcjach par walutowych najczęściej występuje para USD/EUR (tab. 6). Drugie miejsce zajmują operacje USD/JPY. Duże znaczenie ma też para USD/GBP. Udział pozostałych par walutowych nie przekraczał 7\%.

Tabela 6. Udział par walutowych w obrotach na rynku walutowym

Table 6. OTC foreign exchange turnover by currency pair

\begin{tabular}{|c|c|c|c|c|c|c|c|c|c|c|c|c|}
\hline \multirow{2}{*}{$\begin{array}{c}\text { Para } \\
\text { walutowa }\end{array}$} & \multicolumn{2}{|c|}{2001} & \multicolumn{2}{|c|}{2004} & \multicolumn{2}{|c|}{2007} & \multicolumn{2}{|c|}{2010} & \multicolumn{2}{|c|}{2013} & \multicolumn{2}{|c|}{2016} \\
\hline & $\begin{array}{l}\text { mld } \\
\text { USD }\end{array}$ & $\%$ & $\begin{array}{l}\text { mld } \\
\text { USD }\end{array}$ & $\%$ & $\begin{array}{l}\text { mld } \\
\text { USD }\end{array}$ & $\%$ & $\begin{array}{l}\text { mld } \\
\text { USD }\end{array}$ & $\%$ & $\begin{array}{l}\text { mld } \\
\text { USD }\end{array}$ & $\%$ & $\begin{array}{l}\text { mld } \\
\text { USD }\end{array}$ & $\%$ \\
\hline USD / EUR & 372 & 30,0 & 541 & 28,0 & 892 & 26,8 & 1098 & 27,7 & 1292 & 24,1 & 1173 & 23,0 \\
\hline USD / JPY & 250 & 20,2 & 328 & 17,0 & 438 & 13,2 & 567 & 14,3 & 980 & 18,3 & 902 & 17,7 \\
\hline USD / GBP & 129 & 10,4 & 259 & 13,4 & 384 & 11,6 & 360 & 9,1 & 473 & 8,8 & 470 & 9,2 \\
\hline USD / AUD & 51 & 4,1 & 107 & 5,5 & 185 & 5,6 & 248 & 6,3 & 364 & 6,8 & 266 & 5,2 \\
\hline USD / CAD & 54 & 4,3 & 77 & 4,0 & 126 & 3,8 & 182 & 4,6 & 200 & 3,7 & 218 & 4,3 \\
\hline USD / CNY & 0 & 0,0 & 0 & 0,0 & 0 & 0,0 & 31 & 0,8 & 113 & 2,1 & 192 & 3,8 \\
\hline USD / CHF & 59 & 4,8 & 83 & 4,3 & 151 & 4,5 & 166 & 4,2 & 184 & 3,4 & 180 & 3,5 \\
\hline USD / MXN & 0 & 0,0 & 0 & 0,0 & 0 & 0,0 & 0 & 0,0 & 128 & 2,4 & 105 & 2,1 \\
\hline USD / SGD & 0 & 0,0 & 0 & 0,0 & 0 & 0,0 & 0 & 0,0 & 65 & 1,2 & 81 & 1,6 \\
\hline USD / NZD & 0 & 0,0 & 0 & 0,0 & 0 & 0,0 & 0 & 0,0 & 82 & 1,5 & 78 & 1,5 \\
\hline
\end{tabular}

Źródło: opracowanie własne na podstawie: (BIS, 2016).

Również w pozostałych segmentach międzynarodowego rynku finansowego utrzymuje się przewaga dolara amerykańskiego, zarówno na rynku instrumentów dłużnych (rys. 6), jak również pod względem kredytów i depozytów międzynarodowych (tab. 7). 
Tabela 7. Struktura kredytów i pożyczek oraz depozytów międzynarodowych według waluty denominacji (wg bieżącego kursu walutowego)

Table 7. The structure of international loans and deposits by currency (at current exchange rates)

\begin{tabular}{|c|c|c|c|c|c|c|c|c|c|}
\hline \multirow{2}{*}{ Rok } & \multicolumn{2}{|c|}{ EUR } & \multicolumn{2}{|c|}{ USD } & \multicolumn{2}{|l|}{ JPY } & \multicolumn{2}{|c|}{ Pozostałe } & \multirow{2}{*}{$\begin{array}{l}\text { Łącznie } \\
\text { mld USD }\end{array}$} \\
\hline & mld USD & $\%$ & mld USD & $\%$ & mld USD & $\%$ & mld USD & $\%$ & \\
\hline & \multicolumn{9}{|c|}{ Kredyty i pożyczki międzynarodowe } \\
\hline 2002 & 621 & 25,2 & 1338 & 54,3 & 171 & 6,9 & 334 & 13,6 & 2464 \\
\hline \multirow[t]{2}{*}{2015} & 1487 & 21,9 & 3921 & 57,7 & 265 & 3,9 & 1118 & 16,5 & 6791 \\
\hline & \multicolumn{9}{|c|}{ Depozyty międzynarodowe } \\
\hline 2002 & 863 & 28,4 & 1546 & 50,9 & 129 & 4,3 & 499 & 16,4 & 3037 \\
\hline 2015 & 1628 & 24,8 & 3705 & 56,5 & 192 & 2,9 & 1035 & 15,8 & 6560 \\
\hline
\end{tabular}

Źródło: (ECB, 2016, s. 20-23).

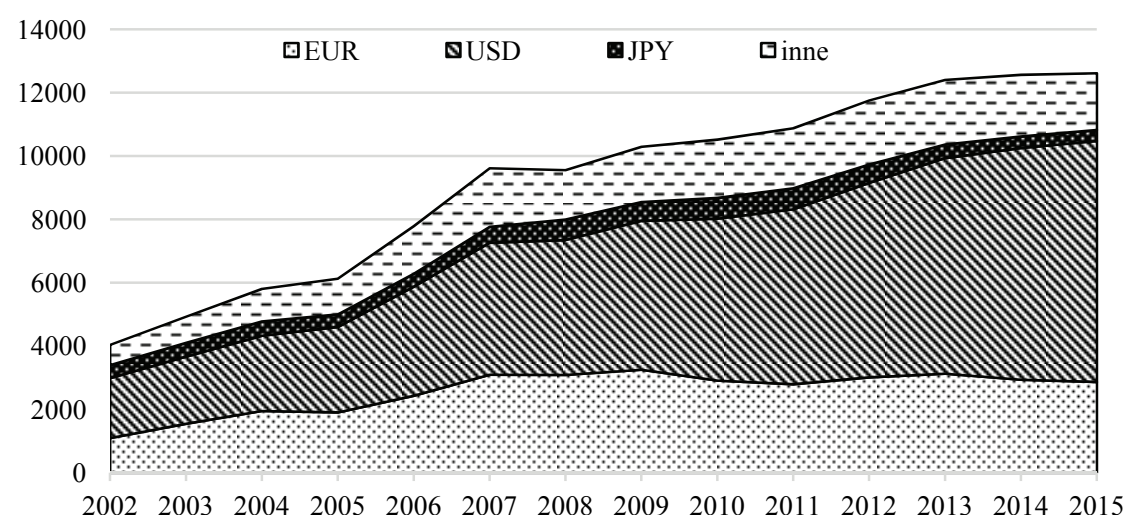

Rys. 6. Udział najważniejszych walut w emisji międzynarodowych instrumentów dłużnych (bez emisji w walucie krajowej, według bieżących kursów walutowych, w mld USD)

Fig. 6. The share of main currencies in international debt (excluding home currency issuance, at current exchange rates)

Źródło: (ECB, 2016, s. 15-16).

Podsumowując, znaczenie walut kluczowych na międzynarodowym rynku finansowym jest zróżnicowane $\mathrm{w}$ zależności od segmentu, choć w każdym obszarze utrzymuje się dominacja dolara amerykańskiego. Pod względem obrotów na rynku walutowym udział dolara w 2016 roku trzykrotnie przewyższał udział euro i w porównaniu do 2001 roku ta przewaga wzrosła. Na rynku kredytowo-depozytowym przewaga dolara również jest prawie 3-krotna w przypadku kredytów i 2-krotna - depozytów. Ponadto, udział dolara zwiększał się. Wyraźnie mniejsza przewaga dolara występuje w przypadku emisji instrumentów dłużnych. Udziały pozostałych walut w emisji dłużnych instrumentów finansowych były niskie. Udział jena spadł z 10,2\% w 2002 do 2,7\% na koniec 2015 roku, udział pozostałych walut zwiększał się w okresie 2002-2007 z 15,9\% do 19,2\%, a następnie spadał do $14,2 \%$ na koniec 2015 roku. Relatywnie wysoki udział euro na rynku dłużnych instrumentów finansowych wynika $\mathrm{z}$ dobrze rozwiniętego rynku obligacji w krajach UGiW i pozyskiwania środków finansowych przez przedsiębiorstwa w formie 
emisji obligacji. Poza tym, podmioty takie jak Europejski Bank Inwestycyjny również odznaczają się wysoką aktywnością w emisji instrumentów dłużnych. Euro ma zdecydowanie mniejsze znaczenie na międzynarodowym rynku akcji, gdzie utrzymuje sie duża przewaga dolara (Mucha-Leszko, 2007).

\section{Wyniki badań: ocena pozycji walut kluczowych w sferze oficjalnej}

Wykorzystanie poszczególnych walut przez sferę prywatną oraz zaufanie do walut determinuje wybór waluty jako środka do przechowywania wartości w sferze oficjalnej, a więc $\mathrm{w}$ tej walucie przechowywane są oficjalne aktywa rezerwowe. Wybór waluty przez władze monetarne innych krajów jako waluty referencyjnej lub zaczepu (anchor currency) oraz do przechowywania oficjalnych rezerw walutowych i dokonywania interwencji na rynku walutowym ma istotny wpływ na jej umiędzynarodowienie.

Jedną z charakterystycznych cech współczesnej gospodarki światowej jest akumulacja rezerw walutowych. Intensyfikacja tego procesu nastapiła w II połowie lat $90 . \mathrm{XX}$ wieku w związku z serią kryzysów walutowych, głównie w krajach azjatyckich. W efekcie światowe rezerwy walutowe wzrosły z 1,4 bln USD (4,5\% PKB) w 1995 roku do 11 bln USD (14,6\%) w 2016 roku (COFER, 2017).

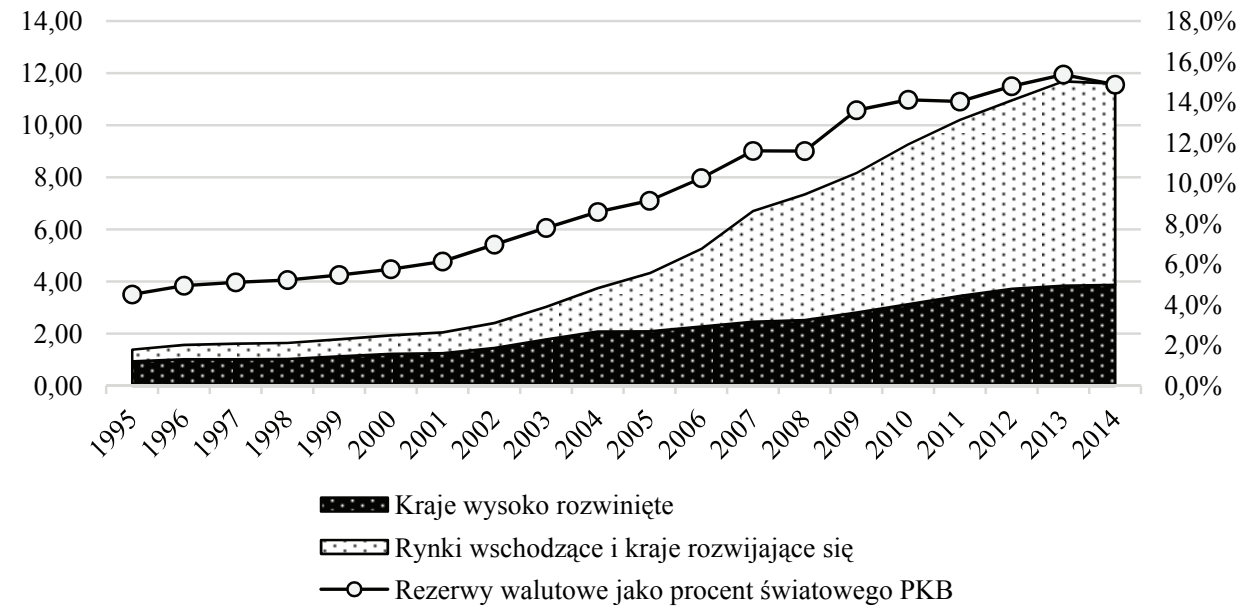

Rys. 7. Wartość światowych rezerw walutowych (w bln USD i \% PKB)

Fig. 7. World foreign exchange reserves (in trillion USD and \% of GDP)

Źródło: opracowanie własne na podstawie: (COFER, 2017; IMF, 2017).

Jak zauważa D.A. Skopiec, akumulacja rezerw walutowych charakteryzuje się koncentracją geograficzną, walutową oraz inwestycyjną (Skopiec, 2016, s. 180). Od 1995 roku nastąiło odwrócenie proporcji pod względem udziałów wakumulacji rezerw walutowych krajów wysoko rozwiniętych i rozwijających się. Jeszcze w 1995 roku udział krajów wysoko rozwiniętych był ponad dwukrotnie wyższy w porównaniu do krajów rozwijających się, a w 2014 roku rezerwy walutowe krajów rozwijających się wynosiły 
7,72 bln USD, stanowiąc 199\% wartości rezerw walutowych krajów wysoko rozwiniętych (rys.7).

Ponadto, koncentrację geograficzną potwierdza udział rezerw zgromadzonych przez 10 krajów o największej akumulacji rezerw walutowych (tab. 8), który w 1990 roku wynosił 58,6\% i wzrósł do 72,7\% w 2015 roku. Zmienił się również udział poszczególnych krajów. W 1990 roku największe rezerwy walutowe posiadała Japonia, następnie USA i Niemcy, a więc kraje wysoko rozwinięte. Chiny zajmowały dopiero 8 pozycję.

Tabela 8. Udział krajów w oficjalnych rezerw walutowych [\%]

Table 8. Countries share of official foreign reserves [\%]

\begin{tabular}{lrlrlrlrlrr}
\hline \multicolumn{1}{c}{1990} & \multicolumn{2}{c}{2000} & \multicolumn{2}{c}{2005} & & \multicolumn{2}{c}{2010} & & \multicolumn{2}{c}{2015} \\
\hline Japonia & 9,3 & Japonia & 19,3 & Japonia & 21,3 & Chiny & 32,8 & Chiny & 32,1 \\
USA & 8,6 & Chiny & 9,1 & Chiny & 21,0 & Japonia & 12,1 & Japonia & 11,6 \\
Niemcy & 8,1 & Hongkong & 5,8 & Korea Płd. & 5,4 & Arabia Saud. & 5,1 & Arabia Saud. & 5,9 \\
Włochy & 7,5 & Korea Płd. & 5,2 & Arabia Saud. & 4,0 & Korea Płd. & 3,3 & Szwajcaria & 5,4 \\
Hiszpania & 6,1 & Singapur & 4,3 & Indie & 3,4 & Brazylia & 3,3 & Korea Płd. & 3,5 \\
Francja & 4,4 & Niemcy & 3,1 & Hongkong & 3,2 & Indie & 3,1 & Hongkong & 3,4 \\
W. Brytania & 4,3 & USA & 3,1 & Singapur & 3,0 & Hongkong & 3,1 & Brazylia & 3,4 \\
Chiny & 3,5 & W. Brytania & 2,1 & Meksyk & 1,9 & Singapur & 2,6 & Indie & 3,2 \\
Szwajcaria & 3,5 & Indie & 2,1 & Malezja & 1,8 & Szwajcaria & 2,6 & Singapur & 2,4 \\
Singapur & 3,3 & Francja & 2,0 & Algeria & 1,4 & Tajlandia & 1,9 & Meksyk & 1,7 \\
Razem & $\mathbf{5 8 , 6}$ & & $\mathbf{5 6 , 2}$ & & $\mathbf{6 6 , 3}$ & & $\mathbf{6 9 , 9}$ & & $\mathbf{7 2 , 7}$ \\
\hline
\end{tabular}

Źródło: opracowanie własne na podstawie: (COFER, 2017).

Koncentracja walutowa światowych rezerw przejawia się dominacją dwóch najważniejszych walut: dolara amerykańskiego i euro z wyraźną przewagą dolara, który utrzymuje swoją pozycję pomimo spadku znaczenia gospodarki amerykańskiej. W drugiej połowie lat 90. udział dolara w światowych rezerwach walutowych wzrastał z 59\% w 1995 roku do 71,5\% w roku 2011, a następnie spadł do poziomu 61,2\% w 2013 roku, po czym tendencja spadkowa została zahamowana. Słabnąca pozycja dolara jako waluty rezerwowej była spowodowana zastępowaniem go przez wprowadzoną w 1999 roku walutę euro, której udział wzrósł z 17,9\% (1999) do 27,7\% w 2009 roku, ale problemy gospodarcze i kryzys zadłużeniowy strefy euro przyczyniły się do ponownego spadku udziału euro w światowych rezerwach walutowych. Udziały pozostałych walut są mało znaczące, w 2016 roku rezerwy w funtach szterlingach oraz jenach japońskich stanowily po 4,5\% światowych rezerw (tab.9).

Można jednak zauważyć, że kryzys finansowo-gospodarczy 2008+ wpłynął na większą dywersyfikację portfela rezerw walutowych i od 2008 roku w coraz większym stopniu stosuje się tzw. waluty alternatywne, których udział w globalnych rezerwach wynosi poniżej 1\% (Mucha-Leszko, 2014). Wysokie rezerwy walutowe zakumulowane przez banki centralne krajów gospodarek wschodzących dają podstawę do sformułowania hipotezy, że w nadchodzących latach zostanie utrzymana tendencja wzrostu znaczenia walut alternatywnych i zmniejszenia udziału dwóch głównych walut rezerwowych: dolara i euro. 
Tabela 9. Struktura walutowa oficjalnych rezerw walutowych (w \%)

Table 9. Currency composition of official foreign reserves (in \%)

\begin{tabular}{|c|c|c|c|c|c|c|c|c|c|c|c|c|c|}
\hline & $\stackrel{2}{2}$ & $\stackrel{\infty}{2}$ & 亏 & 홍 & ֶి & $\stackrel{\overbrace{}}{\stackrel{\sim}{\circ}}$ & 용 & ஓి & $\bar{\Xi}$ & $\stackrel{n}{\stackrel{n}{2}}$ & $\underset{\overbrace{}}{\stackrel{\Xi}{\circ}}$ & $\frac{n}{2}$ & $\frac{0}{0}$ \\
\hline dolar amerykański (USD) & 59,0 & 69,3 & 71,0 & 71,5 & 65,4 & 66,5 & 63,9 & 62,1 & 62,6 & 61,2 & 63,3 & 64,2 & 63,3 \\
\hline euro (EUR) & - & - & 17,9 & 19,2 & 25,0 & 23,9 & 26,1 & 27,7 & 24,4 & 24,2 & 21,9 & 19,7 & 20,3 \\
\hline funt szterling (GBP) & 2,1 & 2,7 & 2,9 & 2,7 & 2,9 & 3,7 & 4,8 & 4,2 & 3,8 & 4,0 & 3,8 & 4,9 & 4,5 \\
\hline jen japoński (JPY) & 6,8 & 6,2 & 6,4 & 5,0 & 4,4 & 4,0 & 3,2 & 2,9 & 3,6 & 3,8 & 3,9 & 4,0 & 4,5 \\
\hline dolar kanadyjski (CAD) & - & - & - & - & - & - & - & - & - & 1,8 & 1,9 & 1,9 & 2,0 \\
\hline dolar australijski (AUD) & - & - & - & - & - & - & - & - & - & 1,8 & 1,8 & 1,9 & 1,9 \\
\hline frank szwajcarski (CHF) & 0,3 & 0,3 & 0,2 & 0,2 & 0,2 & 0,1 & 0,2 & 0,1 & 0,1 & 0,3 & 0,3 & 0,3 & 0,2 \\
\hline marka niemiecka (DEM) & 15,8 & 13,8 & - & - & - & - & - & - & - & - & - & - & - \\
\hline $\mathrm{ECU}$ & 8,5 & 1,3 & - & - & - & - & - & - & - & - & - & - & - \\
\hline frank francuski (FRF) & 2,4 & 1,6 & - & - & - & - & - & - & - & - & - & - & - \\
\hline gulden holenderski (NLG) & 0,3 & 0,3 & - & - & - & - & - & - & - & - & - & - & - \\
\hline inne waluty & 4,9 & 4,5 & 1,6 & 1,3 & 2,0 & 1,7 & 1,8 & 3,0 & 5,5 & 2,8 & 3,1 & 3,1 & 3,3 \\
\hline
\end{tabular}

Źródło: opracowanie własne na podstawie: (COFER, 2017).

Zaprezentowana struktura walutowa rezerw dotyczy rezerw alokowanych, czyli tej części rezerw krajów członkowskich MSW, o której kraje na zasadzie dobrowolności przekazują dane. Istotną część rezerw stanowią jednak rezerwy niealokowane, których struktura nie jest ujawniana. Ich udział w 1995 roku wynosił 25,5\%, następne spadł do 21,2\% w 1997 roku, a od początku XXI wieku cechą charakterystyczną akumulacji rezerw walutowych jest wzrost udziału rezerw niealokowanych, które w 2014 roku stanowily 47,5\%, jednak w latach 2015-2016 ich poziom obniżał się osiagając na koniec 3 kwartału 2016 roku $29,2 \%$ ogółu rezerw walutowych. Przeważająca część tego przyrostu przypada na kraje rozwijające się (COFER, 2017).

Koncentracja inwestycyjna wiąże się $\mathrm{z}$ wymienionymi wcześniej rodzajami koncentracji: geograficzną i walutową i polega na dominacji w światowych rezerwach walutowych rządowych papierów dłużnych krajów emitujących waluty międzynarodowe, a najważniejszą pozycję zajmują obligacje skarbowe emitowane przez rząd USA (Skopiec, 2016, s. 181).

Pozycja waluty rezerwowej powiązana jest również z jej rolą jako waluty zaczepu. Wybór przez władze monetarne kraju stosowanego systemu kursowego ma istotne konsekwencje dla polityki gospodarczej oraz wpływa na rozmiary i strukturę rezerw walutowych oraz na zakres interwencji na rynku walutowym (Kąkol i Mucha-Leszko, 2005). Dane IMF (tab. 10) wskazuja, że w 2015 roku 87 krajów miało waluty powiązane $\mathrm{z}$ walutą referencyjna lub z koszykiem walutowym. Na przestrzeni lat rosła liczba krajów stosujących płynne kursy walutowe, w 1990 roku kraje te stanowiły 41,6\% ogólnej liczby krajów, a w 2015 roku 54,5\%.

Najczęściej wybieraną walutą zaczepu pozostaje dolar (42 kraje w 2015 roku), a drugą pod względem ważności walutą odniesienia jest euro ( 25 krajów w 2015 roku). Ponadto, zarówno euro, jak i dolar często wchodzą również w skład koszyków walutowych pełniących funkcję zaczepu. Silna pozycja dolara jako wartości referencyjnej dla innych walut wynika $\mathrm{z}$ jego relatywnie stabilnej wartości, dużego zaufania podmiotów 
zagranicznych oraz rozwiniętych powiązań handlowych i inwestycyjnych, jak również jest skutkiem kontynuowania przyzwyczajeń przez kraje, które w przeszłości stosowały dolara jako walutę zaczepu. $Z$ kolei euro wybierane jest jako waluta odniesienia głównie przez kraje europejskie, w wyniku przystapienia do mechanizmu ERM II krajów planujących członkostwo w strefie euro lub poprzez jednostronne powiązanie z euro.

Tabela 10. Wykorzystanie walut w funkcji waluty referencyjnej (zaczepu)

Table 10. The use of currencies in function of reference currency (anchor)

\begin{tabular}{|c|c|c|c|c|c|c|c|c|c|c|c|c|}
\hline \multirow{3}{*}{$\begin{array}{c}\text { Liczba krajów (odsetek } \\
\text { krajów w \%) }\end{array}$} & \multicolumn{12}{|c|}{ Lata } \\
\hline & \multicolumn{2}{|c|}{1976} & \multicolumn{2}{|c|}{1983} & \multicolumn{2}{|c|}{1990} & \multicolumn{2}{|c|}{1998} & \multicolumn{2}{|c|}{2013} & \multicolumn{2}{|c|}{2015} \\
\hline & L. & $\%$ & L. & $\%$ & L. & $\%$ & L. & $\%$ & L. & $\%$ & L. & $\%$ \\
\hline $\begin{array}{l}\text { Systemy kursu stałego, } \\
\text { kurs centralny określony } \\
\text { wobec: }\end{array}$ & & & & & & & & & & & & \\
\hline SDR & 12 & 9,4 & 15 & 10,3 & 6 & 4,0 & 4 & 2,2 & 0 & 0,0 & 0 & 0,0 \\
\hline $\begin{array}{l}\text { Dolara } \\
\text { amerykańskiego }\end{array}$ & 54 & 42,2 & 38 & 26,2 & 30 & 19,9 & 24 & 13,1 & 44 & 23,0 & 42 & 22,0 \\
\hline Franka francuskiego & 13 & 10,2 & 13 & 9,0 & 14 & 9,3 & 15 & 8,2 & 0 & 0,0 & 0 & 0,0 \\
\hline Euro & 0 & 0,0 & 0 & 0,0 & 0 & 0,0 & 0 & 0,0 & 27 & 14,1 & 25 & 13,1 \\
\hline $\begin{array}{l}\text { Innej jednostki } \\
\text { pieniężnej }\end{array}$ & 7 & 5,4 & 5 & 3,4 & 5 & 3,3 & 12 & 6,6 & 8 & 4,2 & 8 & 4,2 \\
\hline Innego koszyka walut & 7 & 5,5 & 23 & 15,9 & 33 & 21,9 & 27 & 14,8 & 13 & 6,8 & 12 & 6,3 \\
\hline $\begin{array}{l}\text { Systemy kursu płynnego } \\
\text { (kraje stosujące } \\
\text { bezpośredni cel } \\
\text { inflacyjny, cel w postaci } \\
\text { kontroli podaży } \\
\text { pieniądza i inne) }\end{array}$ & 35 & 27,3 & 51 & 35,2 & 63 & 41,6 & 101 & 55,1 & 99 & 51,8 & 104 & 54,5 \\
\hline Razem & 128 & 100 & 145 & 100 & 151 & 100 & 183 & 100 & 191 & 100 & 191 & 100 \\
\hline
\end{tabular}

Źródło: (IMF 1977, s. 214-215; IMF 1983, s. 21; IMF 1990, s. 140-141; IMF 2013, s. 14-16; IMF 2015, s. 13-14).

Wybór poszczególnych walut jako wartości referencyjnej oraz przechowywanie w nich oficjalnych rezerw walutowych determinuje wykorzystanie tych walut w kolejnej funkcji pieniądza międzynarodowego - jako walutę dokonywania interwencji na rynku walutowym. Ocena struktury walutowej interwencji jest niezwykle trudna, ponieważ większość krajów nie publikuje takich informacji, a dostępne dane są bardzo ograniczone. Można natomiast $\mathrm{z}$ dużą pewnością stwierdzić, że interwencje na rynku walutowym dokonywane są przede wszystkim przez kraje stosujące systemy kursów stałych lub płynnych kierowanych, które wykorzystują w tym celu walutę referencyjną. Możliwość dokonywania interwencji warunkowana jest posiadanymi rezerwami walutowymi.

\section{Perspektywy zmian}

Choć na przestrzeni analizowanych lat nie nastapiły rewolucyjne zmiany dotyczące pozycji walut kluczowych, a wydarzeniem, które w największym stopniu wpłynęło na wykorzystywanie walut $\mathrm{w}$ funkcjach pieniądza międzynarodowego było zastapienie 11 walut krajów europejskich walutą euro w 1999 roku, to w nadchodzących latach ewolucja MSW może oznaczać również umocnienie bądź osłabienie znaczenia pewnych walut, bądź też pojawienie się nowego pieniądza międzynarodowego. 
Eksperci (UNCTAD, 2015) dostrzegają wiele wad międzynarodowego systemu walutowego i oceniają, że obecnie cechuje go znaczna niestabilność w dostarczaniu płynności międzynarodowej, a ponadto nie jest w stanie zapewnić odpowiednich warunków dla pokryzysowej odbudowy gospodarek. Wskazują trzy fundamentalne wyzwania stojące przed współczesnym międzynarodowym systemem walutowym.

Pierwszy problem dotyczy dostarczania płynności międzynarodowej. Tradycyjnie, podmioty z różnych krajów akceptuja jedną lub kilku walut narodowych jako środek płatniczy, rozliczeniowy lub przechowywania wartości $\mathrm{w}$ ramach prowadzonej międzynarodowej działalności gospodarczej i finansowej. Od końca II wojny światowej wszystkie wymienione funkcje pieniądza międzynarodowego pełnił dolar amerykański, ale wiązało się to $\mathrm{z}$ dużymi wahaniami płynności międzynarodowej oraz zmianami realnych kursów walutowych. Ponadto, globalizacja rynku finansowego i rosnąca rola prywatnych pośredników finansowych $\mathrm{w}$ dostarczaniu płynności międzynarodowej potęgują złożoność tego problemu.

Drugie wyzwanie to zapewnianie dostęu do krótkoterminowej płynności w celu reagowania na wstrząsy. Międzynarodowy Fundusz Walutowy został w taki sposób skonstruowany, aby udostępniać bieżące środki finansowe krajom i zapobiegać wykorzystywaniu przez władze krajowe takich instrumentów wpływających na płynność finansową kraju, jak ograniczenia handlowe i konkurencyjna dewaluacja walut. Jednak kraje rozwijające się coraz częściej rezygnowały z pomocy IMF, zwłaszcza w następstwie kryzysu azjatyckiego w latach 1997-1998, na rzecz gromadzenia dużych rezerw walutowych, które mają zapewniać swoiste zabezpieczenie i pierwszą linią obrony przed wstrząsami zewnętrznymi.

Trzeci problem do rozwiązania to zapewnienie sprawiedliwego podziału kosztów przywracania równowagi $w$ bilansach obrotów bieżących. Asymetryczne procesy dostosowawcze implikowane ograniczaniem wydatków w krajach deficytowych bez równoczesnego wzrostu wydatków w krajach nadwyżkowych to tzw. „stronnicze restrykcje" (contractionary bias) międzynarodowego systemu walutowego. Ma to szczególnie niepożądane skutki dla dynamiki globalnego wzrostu gospodarczego w sytuacji, jaką mamy obecnie, czyli powolnego wychodzenia z kryzysu.

W takich warunkach międzynarodowy system walutowy jest źródłem niestabilności oraz nierównowag makroekonomicznych. Niezbędne jest zatem podjęcie działań w celu dostosowania zasad funkcjonowania międzynarodowego porządku walutowego do bieżącej sytuacji na globalnym rynku. Do tej pory proces zmian dostosowujących zasady funkcjonowania międzynarodowego systemu walutowego do globalnego wymiaru procesów rozwoju ekonomicznego odbywał się bardziej na zasadzie działań doraźnych niż zmian systemowych.

Potrzeba przeprowadzenia gruntownej reformy MSW, w tym jego struktury i zasad funkcjonowania, była szczególnie podkreślana w warunkach kryzysu finansowogospodarczego 2008+. Jednak prezentowane prognozy i scenariusze transformacji MSW istotnie się różnia, dlatego trudno jest jednoznacznie wskazać, jakie skutki zmiany te będa miały dla pozycji walut kluczowych. Interesująca analiza kierunków transformacji MSW została przedstawiona przez ekonomistów w 2011 roku (Angeloni i in., 2011), w której podkreślono trzy najbardziej prawdopodobne scenariusze zmian: 1) reformy istniejącego systemu walutowego, 2) transformacji obecnego systemu walutowego w kierunku systemu wielowalutowego, 3) powstania multilateralnego ładu walutowego (Mucha-Leszko, Kąkol, 2012). 


\section{K. Twarowska}

Scenariusz pierwszy oznaczałby utrzymanie dominującej pozycji dolara, a rola euro pozostawałaby w ścisłym związku z sytuacją finansów publicznych i poziomem zadłużenia krajów członkowskich. Poza tym, scenariusz przewiduje stopniowe umacnianie chińskiego systemu walutowego i wiązanie z systemami pozostałych gospodarek wschodzących.

Drugi scenariusz przewiduje, że dolar nadal będzie pełnił ważną rolę w międzynarodowym systemie walutowym, ale jako jedna z trzech głównych walut wraz z euro i renminbi, które zyskają na znaczeniu jako waluty rezerwowe, zaczepu i w sferze transakcji prywatnych.

Najbardziej radykalne zmiany przewidziano w scenariuszu trzecim opisującym wprowadzenie multilateralnego porządku walutowego przez nadanie większego znaczenia walucie umownej, jaką są SDR-y i ich szerokie zastosowanie w funkcjach waluty światowej, np. fakturowania, zaczepu oraz gromadzenia rezerw. Sama koncepcja pieniądza globalnego nie jest nowa, bo sięga m.in. do propozycji J.M. Keynesa z lat 40. XX wieku, ale jest trudna do wprowadzenia w życie, ponieważ wymaga delegowania uprawnień do instytucji międzynarodowych.

Z kolei J. Bilski (2015) uważa, że ewolucja finansów międzynarodowych zmierza w kierunku wykształcenia się sferycznego systemu walutowego, składającego się z trzech poziomów: pierwszy tworzony jest przez dolara jako walutę kluczową, drugim poziomem są waluty międzynarodowe o charakterze regionalnym, a trzecim są waluty pozostałych państw nieaspirujące do pełnienia funkcji międzynarodowych. J. Bilski podkreśla, że taka konstrukcja światowego systemu walutowego staje się coraz bardziej realna i - co istotne stanowi efekt działania sił rynkowych. Choć realizacja poszczególnych scenariuszy nie jest pewna, to niewątpliwie można wskazać czynniki, które będą wpływały na zmiany pozycji walut kluczowych, należą do nich:

- narastające nierównowagi płatnicze i brak skutecznych instrumentów do zapobiegania realizacji przez kraje konkurencyjnej dewaluacji walut,

- wzrost znaczenia krajów rozwijających się, głównie Chin, w światowym handlu, i przepływach kapitału,

- dynamiczny rozwój rynku finansowego,

- $\quad$ wzrost ryzyka na międzynarodowym rynku finansowym związanego z globalizacja oraz efektami zarażania rynków i przenoszenia zjawisk kryzysowych (contagion effect),

- $\quad$ kryzys zadłużeniowy w strefie euro, brak postępów w integracji europejskiej, sygnały o dezintegracji Unii Europejskiej oraz rozwój poglądów eurosceptycznych,

- $\quad$ wykorzystanie przez banki centralne krajów wschodzących walut alternatywnych jako walut inwestowania aktywów rezerwowych, ponieważ uzyskują wyższe korzyści niż w przypadku stosowania dolara i euro.

\section{Podsumowanie}

W analizowanym okresie coraz wyraźniejsze stawały się dysproporcje w globalnych stosunkach walutowych. Utworzenie obszaru wspólnej waluty w Unii Europejskiej, uważane za przełomowe wydarzenie w funkcjonowaniu MSW, nie doprowadziło do oczekiwanych zmian pozycji głównych walut i uzyskania przez euro pozycji drugiej waluty globalnej, konkurującej skutecznie $\mathrm{z}$ dolarem w pełnieniu funkcji pieniądza światowego 
w sferze prywatnej i oficjalnej. Euro pozostaje walutą regionalna, a dominacja dolara utrzymuje się od lat 40. XX wieku (Mucha-Leszko, Kąkol, 2012). Ponadto, rosnący od lat potencjał gospodarczy i handlowy Chin oraz transformacja układu sił gospodarczych nie znajduje odzwierciedlenia $\mathrm{w}$ zmianie pozycji walut krajów rozwijających się $\mathrm{w}$ pełnieniu funkcji pieniądza światowego i chiński renminbi nadal pozostaje walutą o relatywnie niewielkim znaczeniu na rynku międzynarodowym.

Przedstawione powyżej argumenty uzasadniają postawioną we wstępie hipotezę, że wspótczesny międzynarodowy system walutowy oparty na walutach kluczowych nie odzwierciedla istniejqcego uktadu sit gospodarczych. Ponadto, przeprowadzona analiza może być podstawą do dalszych pogłębionych badań nad przyszłym kształtem międzynarodowego porządku walutowego oraz poszukiwaniem odpowiedzi na pytanie: $C z y$ wspótczesna gospodarka światowa może efektywnie funkcjonować jako system wielodewizowy (oparty na kilku walutach kluczowych) czy lepszym rozwiqzaniem bytoby utworzenie jednego globalnego pieniqdza jako podstawy porzadku walutowego?

Odpowiedź na to pytanie nie jest prosta i choć wiele okoliczności przemawiałoby za wprowadzeniem jednego pieniądza międzynarodowego, to realna ocena skutków takiego działania ex ante nie jest możliwa. Ponadto, konieczność utworzenia ponadnarodowej instytucji monetarnej pełniącej funkcje banku centralnego i przekazania suwerennej wcześniej polityki pieniężnej, zapewne zniechęcałaby kraje do realizacji takiego scenariusza transformacji MSW. Dowodem na to jest chociażby brak gotowości części krajów UE na przekazanie realizacji polityki pieniężnej Europejskiemu Bankowi Centralnemu czy brak jednomyślności krajów co do rozszerzenia kompetencji IMF, które pozwoliłyby na realizację skutecznej polityki uniemożliwiającej stosowanie przez kraje strategii konkurencyjnej dewaluacji walut.

\section{Literatura}

Angeloni, I., Bénassy Quéré, A., Carton, B., Darvas, Z., Destais, Ch., Pisani-Ferry, J., Sapir, A., Vallee, S. (2011) Global currencies for tomorrow: a European perspective, Bruegel Brinluept Series, XIII.

Bacchetta, P., van Wincoop, E. (2002). A theory of currency denomination of international trade. ECB Working paper, 177.

Białowąs, T. (2016). Rola euro w fakturowaniu eksportu towarów w latach 1999-2014. Finanse, Rynki Finansowe, Ubezpieczenia, 3(81), 5-14.

Bilski, J. (2015). Pieniądz międzynarodowy w powojennej historii międzynarodowego system walutowego. Teoria i praktyka. Acta Universitatis Lodziensis. Folia Oeconomica 5 (316), 5-25.

BIS (2005). Central Bank Survey of Foreign Exchange and Derivatives Markets Activity, Basel, March.

BIS (2016). Trennial Central Bank Survey. Foreign exchange turnover in April 2016. Monetary and Economic Department, September 2016. Pobrane 19 lutego 2017 z: http://www.bis.org/publ/rpfx 16fx.pdf

Chinn, M., Frankel, J.A. (2005). Will the euro eventually surpass the dollar as leading international reserve currency. NBER Working Paper 11510, July.

Chinn, M., Frankel, J.A. (2007), Will the Euro Eventually Surpass the Dollar as Leading International Reserve Currency. W: R.H. Clarida (red.) G7 Current Account Imbalances: Sustainability and Adjustment (s. 283322). University of Chicago Press.

COFER (2017). Currency Composition of Official Foreign Exchange Reserves, International Monetary Fund. Pobrane 19 lutego $2017 \mathrm{z}$ : http://data.imf.org

Cohen, B.J. (2000). Life at the Top: International Currencies in the Twenty-First Century. Princeton Essays in International Finance, No 221, December.

Cooper, R (2000). Key currencies after the euro. W: R. Mundell, A. Clesse (red.) The euro as a stabilizer in the international economic system, Kluwer, Boston.

Devereux, M., Shi, S. (2005). Vehicle currency. Mimeo, University of British Columbia. 
ECB (2016). The international role of the euro. Interim report. European Central Bank. June.

Eichengreen, B. (1998). The euro as a reserve currency. Journal of the Japanese and International Economies, 12.

Frankel, J.A. (2000). Impact of the euro on members and non-members. W: R. Mundell, A. Clesse (red.) The euro as a stabilizer in the international economic system, Kluwer, Boston.

Galati, G.G., Wooldridge, P. (2006). The euro as the reserve currency: a challenge to the pre-eminence of the US dollar? BIS Working Papers, No 218, October.

Gaspar, V. (2004). Financial integration and the international role of the euro. Euro at Five: Ready for a Global Role, Institute for International Economics, Washington, DC, 26 February.

Goldberg, L.S., Tille, C. (2009). Micro, macro, and strategic forces in international trade invoicing. NBER Working Paper, 15470.

Hartmann, P., Issing, O. (2002). The international role of the euro. Journal of Policy Modeling, 24(4), 315-345.

IMF (1977). Exchange Rates, June 30, 1976, 1976, IMF Survey, July 19.

IMF (1983). Exchange Rates and Exchange Arrangements, December 31, 1982, 1983, IMF Survey, January 24.

IMF (1990). Exchange Rates and Exchange Arrangements, March 30, 1990, IMF Survey, vol 19 no. 13.

IMF (2013). Annual Report 2013. Appendix II. Financial Operations and Transactions..

IMF (2015). Annual Report 2015. Appendix II. Financial Operations and Transactions.

IMF (2017). World Economic Outlook Database October 2016. Pobrane 19 lutego 2017 z: http://www.imf.org

Kąkol, M., Mucha-Leszko, B. (2005). Znaczenie euro jako waluty światowej. W: B. Mucha-Leszko (red.) Współczesna gospodarka światowa. Główne centra gospodarcze. Wydawnictwo UMCS, Lublin,169-202.

Kenen P.B. (1983). The role of the dollar as a international currency. Occasional Papers 13, Group of Thirty, New York.

Lai, E.L.-C., Yu, X. (2014). Invoicing Currency in International Trade: An Empirical Investigation and Some Implications for the Renminbi, The World Economy.

Mucha-Leszko, B. (2005). Rozwój powiązań w gospodarce światowej - etapy globalizacji i regionalizacja procesów gospodarczych. W: B. Mucha-Leszko (red.) Współczesna gospodarka światowa. Główne centra gospodarcze. Wydawnictwo UMCS, Lublin, 15-114.

Mucha-Leszko, B. (2007). Strefa euro. Wprowadzanie, funkcjonowanie, międzynarodowa rola euro. Lublin: Wydawnictwo UMCS.

Mucha-Leszko, B. (2013). Hiszpania w unii walutowej. Annales UMCS. Sectio H Oeconomia, 47(1), 107-120.

Mucha-Leszko, B. (2014). Znaczenie i perspektywy euro w funkcji waluty rezerwowej. Annales UMCS. Sectio H Oeconomia, 48(1), 151-160.

Mucha-Leszko, B., Kąkol, M. (2012). Globalizacja i zmiany w układzie sił gospodarczych a międzynarodowy system walutowy. W: E. Molendowski (red.) Globalizacja i regionalizacja we współczesnym świecie (s. 313-322). Wydawnictwo Uniwersytetu Ekonomicznego w Krakowie.

Mucha-Leszko, B., Kąkol, M. (2013). Perspektywy euro jako waluty międzynarodowej. Studia Ekonomiczne. ZN UE $w$ Katowicach, 129, 97-106.

Oręziak, L. (2001). Główne waluty międzynarodowe. Bank i Kredyt, 9. Bankowe ABC, 76.

Pszczółka, I. (2011). Współczesne waluty międzynarodowe. CeDeWu.pl, Warszawa 2011.

Skopiec, D.A. (2016). Akumulacja oficjalnych rezerw walutowych jako determinanta stabilności współczesnej gospodarki światowej. Studia Ekonomiczne. ZN UE w Katowicach, 266, 178-188.

SWIFT (2015). Worldwide Currency Usage and Trends. Information paper prepared by SWIFT in collaboration with City London and Paris EUROPLACE, December.

Truman, E.M. (2004). The Limits of Exchange Market Intervention. W: C. Fred Bergsten and John Williamson (red.) Dollar Overvaluation and the World Economy (s. 247-265). Washington, Institute for International Economics.

UNCTAD (2015). Systemic Challenges in the International Monetary System. Trade and Development Report. Making the international financial architecture work for development, Chapter III.

UNCTAD (2017). UNCTADstat. Pobrane 19 lutego 2017 z: http://unctadstat.unctad.org. 